\title{
A Review of Phenological Patterns of Amphibians and Reptiles in Central Mediterranean Ecoregion
}

\author{
Pierangelo Crucitti \\ Società Romana di Scienze Naturali, SRSN, Roma, \\ Italy
}

\section{Introduction}

Phenology is consistent with different definitions and topics: (i) the study of seasonal phenomena conditioning lifestyle of organisms; (ii) the science of recording and classifying the remarkable occurrence of animal development, particularly ectothermic ones, e.g. insects and lower vertebrates; (iii) the branch of Biology which studies the relationships between climatic factors and various seasonal events of plant and animal lives; the last one being suitable to the problems discussed in this chapter (Lanza et al., 1982; Brandmayr \& Ghirardelli, 1995; Speight et al., 2008). Phenological data are represented by climatic factors seasonal events and related parameters, especially temperature and rainfall - in their correlation with various aspects of animal lifestyles. So, phenology and bioclimatology are somewhat subsidiary subjects. Biological patterns are represented, in their seasonal context, by a remarkable amount of data concerning different, ecological and ethological, items; 1reproductive activity; i.e. variation in space and time of reproductive success and its relationships with macroclimatological (regional), meso- and microclimatological (local) patterns; 2- population turnover (population size, sex and sub adult/adult ratios); 3- site fidelity and its variation from year to year; 4- foraging behaviour (diet composition; prey predator relationships and its seasonal variability). Current problems stimulate some basic questions. Beginning from the predictable assumption that weathering events strongly affect daytime and seasonal activities and, to a certain extent, the distribution, both local and worldwide, of amphibians and reptiles, what contribution may arise from the knowledge of phenological patterns to the dramatic problems of the decline of their populations in disparate regions of the world? Recent changes of yearly reproductive phenology together with the modification of species distributional area might be related to, or induced by, the so called "global warming"? Predictive models and related strategies of conservation measures may stimulate the increase of our knowledge in this field of research. Scientific literature suggests that the Mediterranean area as a whole is one of the most sensitive landscape to current climatic modifications (Gatto et al., 2009). Climatic scenario for the near future shows for the Mediterranean area, and particularly for Italy, an increase of heat waves and natural dramatic events such as inundation and / or dryness with a significant loss of marine, freshwater and terrestrial biodiversity. Global Climatic Changes and its impact events on ecosystems and species may be grouped in the following categories: physiology 
and behaviour; yearly biological cycles; geographical distribution; composition of ecological communities including interactions between species (Nanni et al., 2009). At the global level, the imminent extinction emergency of Amphibia is a tribute to a number of additional threats such us diseases, invasive species, pollution and over-exploitation (Alford \& Richards, 1999; Collins \& Storfer, 2003; Stuart et al., 2004; Di Rosa et al., 2007).

\section{Amphibians and reptiles in the central mediterranean ecoregion}

Climate. It appears as a petitio principi that a large part of the Mediterranean area is characterized by a typical Mediterranean climate with a dry season generally as long as the summer period when air temperature is higher. However, climatic scenario is much more complicated, e. g. 15 different bioclimatic units are reported for Latium, Central Italy (Blasi, 1994; Blasi \& Michetti, 2007). Climatic scenario of the Italian territory shows, at present, an increase of daily, maximum and minimum, temperatures, coupled with the increase of mid temperature and in accordance with the increase of the frequency of heat waves which have trebled in the last fifty years; besides, all the Italian territory is characterized by a significant decrease of feeble rainy days, contrary to the increase of intense rainy days in some regions of northern Italy (Lionello et al., 2009). The Sardinian climate especially due to the position of this island in the Tyrrhenian Sea, overlapping with its typical mountainous territory. However, desertification, as pointed out by aridity and drought indexes, shows for Sardinia an $88.7 \%$ of the regional surface (Sicily 95\%; Apulia 72\%); for the Italian territory, desertification increases $6.5 \%$ between 1951 and 1980, at present being about 18\% of the whole surface of Italy (Sciortino et al., 2009).

Biodiversity. The Mediterranean Basin, a hyper-hotspot of biodiversity, is the largest among the five Mediterranean systems of the world and includes at least ten mini-hotspot of animal, plant and landscape diversity (Blasi et al., 2007). It is well known that Italy shows an extraordinary richness in species, communities and landscapes, the significance and state of conservation of this biological diversity is self-evident (Bianchi et al., 2002; Minelli et al., 2002). The position of the Central Mediterranean Ecoregion makes this landscape a remarkable reservoir of biodiversity. As a mere example, in the Region of Latium, a landscape of just $17,227 \mathrm{~km}^{2}, 5.7 \%$ of the Italian political territory, 3228 species and subspecies of vascular plants (2000 only in the Province of Rome) were recorded together with some 70 terrestrial mammals, 23 of which are bats (Chiroptera) out of 34 species of bats of four families belonging to the Italian fauna (Crucitti, 2011; Veith et al., 2011). Amphibians and Reptiles are represented in the Italian territories considered as a biogeographical unit (mainland and peninsular Italy, Sicily, Sardinia, Corsica and related archipelagos; besides, the Nice area, Canton Ticino, Istria, Quarnaro Islands and neighbouring Dalmatian coastal area; finally, the Maltese Islands) by some 100 species and species complex (Bologna et al., 2000; Sindaco et al., 2006; Lanza et al., 2007; Corsetti \& Romano, 2008; Bassu et al., 2008, 2010; Corti et al., 2011: Luiselli, in verbis VIII.2011) (Tab. 1). More generally, Sardinia and Corsica, among the largest islands in the Tyrrhenian Sea, are known to harbour a comparatively high number of endemic species among different taxa, both animals and plants (Grill et al., 2007); recent results of researches in Pipistrellus and Hypsugo cryptic diversity highlight the importance of Sardinia as a major Mediterranean hotspot for microbat biodiversity (Veith et al., 2011). 


\begin{tabular}{|c|c|c|c|}
\hline Taxon $\quad$ Area & I T A L Y & Central Italy & Sardinia \\
\hline AMPHIBIA & $43(20+23)$ & $16(7+9)$ & $10(6+4)(8)$ \\
\hline REPTILIA & $55(9+27+19)$ & $24(7+7+10)$ & $20(6+9+5)(4)$ \\
\hline
\end{tabular}

Table 1. Total numbers, outside parentheses, of Amphibia and Reptilia species in the Italian fauna. Amphibia: the first and second number (inside parentheses) indicates species and species complex of Caudata and Anura, respectively. Reptilia: the first, second and third number (inside parentheses) indicate the species of Chelonii, Sauria and Serpentes, respectively. Sardinia: numbers inside the second parentheses indicate the endemic species for each taxon.

\section{Current methodological problems}

For the goal of this contribution, Central Italy and Sardinia, belonging to the Central Mediterranean Ecoregion, have been selected as paradigmatic areas, a by-product of our specific interest and field experience. Several methods are available to provide suitable data in the study of vertebrate phenology, especially ectothermic ones, commonly related to the problems investigated in a given research. Some remarkable kinds of methodological approaches as emerging from current literature in the topics mentioned in the previous paragraph are uninterruptedly discussed.

i. Field studies on the reproductive phenology during the annual cycle of a given species in relation to its ecology, particularly population dynamics, sex ratio, average growth rate etc. in other words the study of the influence of environmental conditions on adult body size and other biological parameters. In this field of investigation, particularly intriguing are the numerous cases represented by newt populations living at persistent vs. temporary ponds, i.e. in a predictable / unpredictable environments which require different, counterintuitive, life strategies. In this context, experimental drawings generally require the following steps:

a. the choice of the species;

b. the choice of the study area and sites with a concise physiographical description;

c. the collection of data on the (local) climate, e.g. mean of the minimum air temperature and mean rainfall, recorded monthly during the whole period of observations;

d. the recurrence (monthly, weekly) of catching individuals and correlated methods of recognition such as belly-pattern recorded photographically and toe-clipping marking (less invasive methods are desirable though recent observations agree with the absence of secondary effects provoked by the removal of a single finger from one leg (see Sacchi \& Delaugerre, 2011 for the Gekkonidae Hemidactylus turcicus (Linnaeus, 1758)) including sex and secondary sexual characters together with biometrical data;

e. the adoption of suitable indexes to derive the absolute size of population and its dynamic - variation of size through time, generally one year (Accordi et al., 1990; Angelini et al., 2001, 2010 a, b). 
ii. Topical issues in Amphibians. The detrimental role of climate change by itself or in association with other anthropogenic stressors - structural modifications of native habitat, pollutant releases, emerging infectious diseases, invasive species, overexploitation - as the main causes of amphibian populations' decline in Europe and elsewhere, has been pointed out. Evidence of climate-linked amphibian declines in Italy has been highlighted, first adopting for the presence data of Italian amphibians, the CKmap 5.3.8 software, the largest and most authoritative databank of faunistic knowledge of the Italian fauna, 500,000 records of approximately 10,000 terrestrial and freshwater species (Stoch, 2000-2005; Ruffo \& Stoch, 2005). The CKmap database contains 12,585 records representing the current knowledge of the distribution in Italy of the 36 amphibian species of the Italian fauna. Species occurrence within any of the 3557 cells of UTM grid, 10x10 km, that intersect the Italian territory is reported; in each cell one single record is reported. Ancillary information, e.g. the year of last observation is provided for each cell. Nineteen species, out of which 12 Anura and 7 Caudata (salamandrids), have been analyzed according to their present status ( $\mathrm{D}^{\prime}$ Amen \& Bombi, 2009). Environmental data, i.e. climate change, habitat alteration and solar irradiation incidence have been analyzed for the Italian territories in their possible association with amphibians declines. SCIA databank, the National System for collection, elaboration, and dissemination of Climatologic data of environmental interest, provides annual mean values of annual number of dry days, annual cumulate precipitation, and annual mean temperature for the period 1961-1990. Habitat modifications was obtained by calculating the percentage of agricultural and urban land cover classes (Corine Land Cover 1990 data, provided by the Institute for Environmental Protection and Research, ISPRA). Finally, the map of horizontal irradiation available from Joint Research Centre has been utilized as a proxy of geographic differences in solar irradiation incidence relative to the period 1981 - 1990. In order to measure the influence of these three variables on amphibians' decline, auto covariate models on cell status with a binomial probability distribution ("stable" = 0 ; "decline" = 1) have been fitted together with a logit link utilizing environmental variables as predictors. Results reveal an alarming situation. The status of "decline" was assigned to $17.04 \%$ cells, the status of "stable" to $82.96 \%$ cells. A large fraction of amphibian species $(52.63 \%)$ had $15-20 \%$ decline cells. Five species with the highest rate of local decline RLD ("decline" / "stable" + "decline"), Pelobates fuscus (Laurenti, 1768), Bombina pachypus (Bonaparte, 1838), Discoglossus pictus Otth, 1837, Salamandra atra Laurenti, 1768 and Triturus carnifex have RLD 54.35, 37.54, 32.08, 23.33 and 20.31 respectively, while the lowest RLD' values are typical of some, yet relatively common species, the green frogs Pelophylax spp. (D'Amen \& Bombi, 2009). The complex influence of several factors associated with amphibian population declines has been demonstrated thanks to these results. Important evidence of global warming's impacts climatic shifts e.g. the decreasing annual precipitation and increasing temperatures during the warmest months - and its interaction with diseases, for example increased susceptibility to chytrid fungi (Simoncelli et al., 2005), have a strong impacts on amphibians populations, in association with habitat loss too. Human land use patterns, particularly changes linked to urbanization, have substantially contributed to amphibian declines in Italy (Andreone \& Luiselli, 2000). Finally, irradiation, though 
probably not a direct cause of mortality, may have an important role in association with other stressors; the increase in sub-lethal exposures of UV-B radiation and its link with the susceptibility to contaminants and pathogens is paradigmatic ( $\mathrm{D}^{\prime}$ Amen \& Bombi, 2009).

iii. Topical issues in Reptiles. A meaningful example of methodological protocol applied to chelonians, is a recent study on seasonal changes of the diet in Hermann's Tortoises Testudo hermanni hermanni Gmelin, 1789, a threatened species (NT according to the Red List of IUCN). T. h. hermanni is a relatively small (800-1000 $\mathrm{g}$ on average) terrestrial turtles of the family Testudinidae, endemic to Southern Europe. Terrestrial chelonians mostly belonging to the widespread family Testudinidae display a generalized herbivorous or omnivorous feeding habits contrary to most terrestrial vertebrate ectotherms which are exclusively or predominantly carnivorous. Exactly, $66 \%$ of terrestrial chelonians are strictly herbivorous, 33\% are omnivorous (but many are also primarily herbivorous) and only one species, Terrapene carolina (Linnaeus, 1758), is predominantly carnivorous (Luiselli, $2006 \mathrm{a}, \mathrm{b}$ ). T. h. hermanni occupies a wide range of dry sites along coastal areas of Western Central Italy where it is markedly linked to maquis habitat. Phylopatry together with a detailed knowledge of their home ranges based on vegetation and other landmarks is a peculiar trait of their life history. To understand the habitat requirements is strategic, since this tortoise is declining in most part of its range. At least 132 plant species belonging to 46 families, mainly Asteraceae and Fabaceae, are eaten by Hermann's Tortoise (Cheylan et al., 2011). Field studies have been conducted in the coastal pine forest of Castelfusano near Roma, Central Italy, with the aid of faecal-pellet analysis to determine intersexual and interseasonal variation in the diet of this free-ranging population. A third goal of this study is the identification of the most important food plants for this species, discovering any plant species that might be rare but important diet items, their relative abundance being critical to tortoise conservation. The diet of T. h. hermanni has been quantified by analyzing faecal pellets collected during spring and autumn. Tortoises typically defecated during capture and manipulation; on the contrary, individuals may be placed in small cages without any vegetation until defecation occurs, up to $48 \mathrm{~h}$ later in some instances; after, they were released at their capture points. The analysis of faecal pellets, placed in 50\% ethanolwater solution and stored in plastic vials, is described in detail by Del Vecchio et al. (2011). At the same time, plant sampling at the study area has been performed from April to June, and the relative abundance of each plant species has been estimated. Leaves were the most commonly consumed plant structure contrary to seeds and fruits (Del Vecchio et al., 2011). During spring the most important families were Fabaceae, Asteraceae and Poaceae, in autumn Ruscaceae, Fabaceae and Asteraceae; at least 21 plant species were found in males faecal pellets and 18 in females, the composition of the diets in the two sexes being similar both qualitatively and quantitatively. Interseasonal differences in diets reveal interesting pattern; diet composition differs remarkably among seasons, notwithstanding the quantitative compositions of the diet, as revealed by the frequency of consumption of the various food items, were not significantly different between spring and autumn. Carduus, Medicago, Melilotus, Trifolium with some undetermined species of Leguminosae were consumed in spring but not in autumn, contrary to Ruscus which was consumed during autumn but never 
during springtime. Abundances of food availability in the field were strongly uneven, some taxa are extremely abundant e.g. Coronilla emerus, Ruscus aculeatus and Smilax aspera and others extremely rare, e.g. Rosa sempervirens and some Papaveraceae. Five main patterns have been focused; 1 - in the study area, T. h. hermanni is entirely herbivorous; 2 - during spring, leaves are consumed more than flowers or fruits; 3 - the sexes do not differ significantly in dietary composition; 4 - dietary composition of spring has been found significantly different from that of autumn, thus indicating a seasonal change in diet (fruits of some species, e.g. Arbutus unedo, are available in November-December, too late in the season); 5 - tortoises are mostly generalist, the relative abundance of the eaten species is generally higher than that of the species that were not eaten, the foraging strategy of T. hermanni is a mixture between a generalist and a specialist forager. Plants which are preferred because they provide important nutrients or other dietary needs should be carefully managed for the maintenance of this declining species (Del Vecchio et al., 2011). More generally, the genus Testudo is a group of conservation concern - highly vulnerable as a result of habitat destruction, commercial exploitation and overharvesting for food.

An other example of appropriate methodological protocol has been recently applied to the endangered species Hemorrhois (= Coluber) hippocrepis (Linnaeus, 1758), the horseshoe whip snake, a medium sized (up to $180 \mathrm{~cm}$ in length) quick-running terrestrial Colubridae, which actively forages on lizards and mice. The Italian distribution of this snake is limited to Pantelleria island, south of Sicily, and Sardinia, nearly only in the south-western portion of the island. The morphology of the specimens from both the Pantelleria and Sardinia was found to be different from that of mainland conspecific populations from Iberian Peninsula and North Africa, suggesting their indigenous origin (Cattaneo, 1985; Corti et al., 2000; Luiselli et al., 2010). In Sardinia, H. hippocrepis is so rare and localized that this snake was considered to be extinct in 1960. Notwithstanding its occurrence on the island was repeatedly confirmed in recent years, the Sardinian populations have been regarded among the most critically endangered in Europe, this species representing an absolute priority for biodiversity conservation in Italy, low population density, competition with the western whip snake Hierophis (= Coluber) viridiflavus (Lacépède, 1789) and fragmentation of available habitats representing the major threats to its survival (Corti et al., 2000; Filippi \& Luiselli, 2000; Luiselli et al., 2010). A goal of pressing realization is planning helpful instruments for the short- and long-term conservation of H. hippocrepis in Sardinia. First, habitat suitability of the horseshoe whip snake in Sardinia under current environmental conditions has been modelled; the species ecological requirements is projected in future climatic scenarios in order to evaluate the probability of persistence of the species in the study area. Presence data have been derived from CKmap databank. Data indicates the occurrence of the species within the UTM, $10 \times 10 \mathrm{~km}$, grid. Downscaling coarse resolution atlas data is necessary for gaining the spatial accuracy required by conservation initiatives, so 1000 random points all across the study area have been generated and a binary code $(0 / 1)$ has been assigned to the random points according to their relative location, outside (0) or within (1) the range of $H$. hippocrepis. Environmental predictors - land cover, land morphology and human impact layers - in addition to climatic predictors, have been considered in order to take into account as many aspects of the species environmental requirements as possible. Two different time slices, 2020 and 2050, were utilized for projecting habitat suitability into future climate and, 
in addition, percentage of 5 different Corine Land Cover classes in 30 arcsec squares were calculated. Land morphology descriptors were represented by using four variables such as elevation, slope, northness and eastness. The Human Impact Index for representing the human impact on environment with a spatial resolution of $1 \mathrm{~km}$, has been utilized. Finally, five different methods, CTA, GBM, GLM, MARS and RF for modelling habitat suitability have been performed; the models fitted on current conditions were projected into future climatic scenarios. Four retaining models agree in considering suitable, under present conditions, large areas of south-western Sardinia, nevertheless they evidenced an alarming trend for $H$. hippocrepis conservation. All but four squares currently occupied by the snake are expected to lose completely their suitability within 2020 and other two squares became totally unsuitable within 2050 . The consensus maps indicate a reduction of $86.2 \%$ in suitable surface by 2020 and a collapse of $99.2 \%$ by 2050, i.e. to survive in one protected area only, disappearing completely from the other protected areas of the Province of Cagliari. Results demonstrate that climate change must be considered one of the most immediately threatening factor. The only area that is expected to maintain suitable conditions for $H$. hippocrepis under future climate change must be considered as a crucial refuge; this is the case of the site of Community Importance named "Stagno di Cagliari, Saline di Macchiareddu, Laguna di Santa Gilla" although in this site the species is uncommon especially with respect to the sinthopic one Hierophis viridiflavus. Most of the sites inhabited by $H$. hippocrepis are strongly anthropized - sea-side tourism areas with busy roads. However, connectivity among source areas is crucial for conservation of this snake. According to this view the systems of natural corridors connecting various sites of actual presence of the species should be implemented and constantly monitored together with restoration of microhabitats and construction of drinking places and laying sites, strategically important for guarantying the persistence of this attractive species (Bombi et al., 2011).

\section{Some remarkable case studies in amphibia}

A selection of recent Italian literature on this topic is provided. The genus Euproctus includes, at present, two species, E. montanus (Savi, 1838), a Corsican endemism, and E. platycephalus (Gravenhorst, 1829), a Sardinian endemism. Suitable habitats of these newts are the cool and calm waters of streams and rivers (Sardinian species; ponds and pools too) of hilly and mountainous areas. Adults life-cycles is generally characterized by the existence of terrestrial and aquatic phases; the Corsican species may be found in water from March to September, the Sardinian during summer. Contrary to E. montanus, the present distributional area of E. platicephalus is extremely reduced with respect to the past. E. platicephalus is considered as endangered (EN) based on IUCN categories; according to some authors it is, among European newts, the most endangered species. So, this species is a priority for biodiversity conservation in Italy. One of the major threats to the survival of its populations is considered the strong dryness of the last decades and the fragmentation / disappearance of streams, especially during summer. Different altitudinal and optimum ranges of both species indirectly suggests for the Sardinian species a problematic destiny concerning its survival (Andreone \& Luiselli, 2000; Lecis, 2004, 2007) (Tab. 2). Serious consequences for conservation and management often came out from the overlapping between anthropogenic factors and eco-ethological constraints of species and environment. 
Shifting of habitat suitability with climate change could led to population declines for species that are unable to move to new appropriate conditions (Thomas et al., 2004; Araújo et al., 2006; D'Amen \& Bombi, 2009).

\begin{tabular}{|c|c|c|}
\hline Species & Total altitudinal range & Optimal altitudinal range \\
\hline Euproctus platicephalus & $50-1800$ & $400-800$ \\
\hline Euproctus montanus & $15-2200$ & $700-1900$ \\
\hline
\end{tabular}

Table 2. Total and optimal altitudinal range (m a.s.l.) for each species of Euproctus of the Sardinian - Corsican Massif

Salamandra salamandra (Linnaeus, 1758) is the largest Italian newt with a body length up to $28 \mathrm{~cm}$ in Southern Europe. This species occurs mainly in hilly and mountainous areas of the Alpine Arch and the Apennine system, from about the sea level to $1800 \mathrm{~m}$ a.s.l., preferably between piedmont areas to about $1000 \mathrm{~m}$ a.s.l. with a relatively unbroken distribution in mainland Italy - with the exception for the Po Valley - and Calabria; its scattered distribution along the remnants of Italian territories, especially the Central Apennine, is a debated question (see for instance Caldonazzi et al., 2007). S. salamandra occurs mostly in beech, chestnut and oak woods. Adults, strictly terrestrial, are active during the whole year under favourable meteorological conditions. The distribution of $S$. salamandra along the Northern and Central Apennines corroborates the hypothesis of a strong dependence from rainfall, mostly mesophilous sites are inside the area with over $1,000 \mathrm{~mm} /$ year of precipitation (Tedaldi, 2001). The species shows a bimodal pattern of activity, courtship and breeding occurs on land during spring and autumn time. Female sperm storage lasts over one year. Births occur during April and larvae of unusual size are lied down in still water of mountain streams; larvae are found at water up to mid October when metamorphosis occurs (Caldonazzi et al., 2007). Salamandrina is an endemic genus of peninsular Italy. Two species are acknowledged since 2005, S. perspicillata (Savi, 1821) of the Central and Northern Apennine, and S. terdigitata (Lacépède, 1788) of the Southern Apennine - a pattern of parapatrical distribution (Lanza et al., 2009). S. perspicillata shows a relative continuous distribution from the Genoa Province to the whole Latium, from the sea level to over $1900 \mathrm{~m}$ a.s.l. Mesophilous mixed woods and Mediterranean scrub together with caves, debris, pastures, garigues and reforestation areas represents suitable habitats for this, essentially terrestrial, species. Generally, only adult females are found inside water - low running streams or similar bodies, drinking through, stone wells, entrance of caves (Crucitti et al., 2010). Eggs deposition during the aquatic phase is few days vs. few weeks long. A bimodal activity period has been ascertained in Latium in accordance to oviposition time; from September at the onset of January and from February to April, spending unfavourable period inside hypogeal environment. Daily terrestrial activity, during day or night-time, is between sunset and midnight. During light time, activity occurs in moist days and, in this case, shadow sites with litter are preferred (Angelini et al., 2007). Lissotriton italicus (Peracca, 1898) and Lissotriton vulgaris (Linnaeus, 1758), generally known as "water salamanders", are small newts living, often sintopically, in drinking through, irrigation tanks, pools and ponds of hilly and mountainous areas of Central Italy. Reproductive activity of L. italicus is observed mostly between February and May, courtship and eggs deposition during autumn too. This species shows a typical yearly cycle with multiple pattern of four phases - aquatic, 
emigration, terrestrial, immigration. The reproductive activity is especially concentrated between December and February. Between the end of September and the beginning of November, the majority of newts are still terrestrial; in this period males first enter water, where courtship began. Larvae appear during January and their development is completed before the beginning of terrestrial phase. Variation of spermatogenetic pattern occurs during the whole cycle, for example, during the aquatic phase testis are evident, contrary to the terrestrial phase. In summer, newts are active during the first hours of the day and at sunset, when the soil is moist. Diet is extremely varied including both terrestrial insects, especially at larval stage, and aquatic invertebrates, woodlice of the genus Asellus are included in mountain ponds (Scillitani \& Tripepi, 2007). Many studies have been carried out on the ecology of L. vulgaris especially in Northern and Central Europe. In the last twenty years some studies have focused on the ecology of the Italian species Lissotriton meridionalis (Boulenger, 1882). The present distribution of Italian newts have been influenced by historical factors coupled with climatic conditions such as temperature and rainfall (Giacoma, 1988). The annual cycle of a population of this subspecies has been studied at a pond, close to the southern limit of its distributional area, inside the "President's Estate of Castelporziano", few kms south of Rome, one of the last areas of the Tyrrhenian Coast still covered by floodplain forest. A particularly dried climate is typical of Castelporziano and the long summer drought causes ponds to dry up completely. Average water level fluctuates yearly, since water is of rainfall origin. Timing of migration differs significantly from that described in other countries, the Central Italy population is present at water from November to May, much earlier in comparison with Northern populations of L. vulgaris - in England immigration starts in February-March and emigration lasts from July to December. The aquatic period is short compared to that of northern populations and activity during the summer terrestrial phase is scanty. Temperature has a strong influence on the annual reproductive cycle, different water seasons have also been observed in Italy according to latitude and altitude of the breeding sites. Immigration and reproduction take place in December, as soon as weather conditions are favourable. Emigration lasts from April-May, ending before pond desiccation in June. Therefore, summer drought is a limiting factor especially for larval survival. The sex ratio is unbalanced because in particularly dry conditions few females may reach the pond; males, which are at ponds earlier than females, often exceed in breeding populations. The mean body size registered at Castelporziano is the smallest among populations of Central and Northern Italy owing to unfavourable conditions, typical of coastal and xeric habitats; food consumption is irregular especially

\begin{tabular}{|l|l|l|l|l|}
\hline Phases & AQUATIC & EMIGRATION & TERRESTRIAL & IMMIGRATION \\
\hline Lissotriton italicus & $\begin{array}{l}\text { October - } \\
\text { May }\end{array}$ & June & Summer & $\begin{array}{l}\text { September - } \\
\text { November }\end{array}$ \\
\hline $\begin{array}{l}\text { Lissotriton } \\
\text { meridionalis }\end{array}$ & $\begin{array}{l}\text { November - } \\
\text { April }\end{array}$ & April - May & Summer & December \\
\hline
\end{tabular}

Table 3. A prospect of time - dependent phases in the lifecycle of two species of Lissotriton from Central Italy 
during the terrestrial juvenile phase. Fecundity is size-specific, larger females of $L$. meridionalis lay more and larger eggs that hatch earlier (Accordi et al., 1990). Nearly similar patterns have been observed in a population of L. meridionalis living at temporary ponds in the "Bosco di Palo", a WWF Oasis near Rome, characterized by a meso-mediterranean climate; mild winter, summer dryness three months long coupled with abundant rainfall typical of maritime climate. Mediterranean climate allows to anticipate the eggs layering in late fall. Concentration of newts at the water reaches its maximum between February and April. Activity pattern during aquatic phase has been ascertained with a maximum of 14-17 ${ }^{\circ} \mathrm{C}$ and a minimum of $3-6^{\circ} \mathrm{C}$ (Pizzuti Piccoli, 2006/07) (Tab. 3).

\section{Some remarkable case studies in reptilia}

A selection of recent Italian literature on this topic is provided. Among Gekkonidae, four species in Italy, Euleptes europaea (Gené, 1839) is considered Near Threatened (NT), particularly the micro insular or satellite populations of Sardinian and Corsican Archipelagos. This species shows a nocturnal activity pattern, store up on heat during the day better than other species of the family living in the same Corsican habitat, Tarentola mauritanica (Linnaeus, 1758) and Hemidactylus turcicus (Salvidio et al., 2011). Tarentola mauritanica, one of the commonest species of the family, is active in the first hours of the day, during the hottest months and, in the central hours, during the coldest one. Thermoregulatory ability has been developed both on islands and mainland - in this last situation, a noticeable density of its predators, typically snakes, has been observed. Foraging and thermoregulatory activities are carried out on rocky substrata. On the island of Lampedusa (Sicily) and during summer, body temperature is positively correlated with air temperature. However, a decrease of nocturnal activity has been observed after midnight; during the last hour of the day, body temperature shows an increase of about $2^{\circ} \mathrm{C}$, decreasing in the same way at the beginning of nighttimes. With air temperature below $15^{\circ}$ C, the activity is low or scanty, however coastal populations of Tuscany (Central Italy) are active with air temperatures $8-9^{\circ} \mathrm{C}$ and rocky substratum $10^{\circ} \mathrm{C}$ or just upper. Hibernation is not evident in the populations of coastal areas of Sicily, their activity is displayed during the whole year (Aprea et al., 2011). Like Gekkonidae, Scincidae is a family of tropical / subtropical origin; only three species occur in Italy, Chalcides chalcides (Linnaeus, 1758) being the widespread one. This species is active only during the day both in spring and summer; a bimodal pattern of activity has been ascertained, during the central hours of the day and the first hours of the afternoon. Aestivation occurs in August. Active lizards have been observed during winter month too, hot days raging (Caputo et al., 2011 a). Similarly, Chalcides ocellatus (Forskål, 1775) is active from April to October, especially from April to June with a peak of activity during May. Circadian activity pattern during this period appears unimodal, showing a preference for the central and hottest hours of the day; during summer it becomes bimodal, being concentrated during the first hours of the morning and in late afternoon. Activity pattern becomes again unimodal with a peak during the central time of the day in September-October. As a rule, during the second half of October, when thermal fluctuations are especially marked, C. ocellatus is at rest at their hibernation roosts. Populations of coastal sites show scattered winter activity under particularly favourable meteorological conditions. In inland and mountainous areas of Sicily, the phase of 
dormancy lasts up to March. Reproductive season, together with a marked activity pattern, falls between April and May; spermatogenesis is seasonal, spermatogonial proliferation occurs in August and spermiohystogenesis in April-May shortly before mating. Gravid females are found in Sicily beginning from the second half of May. In southern sites, two or three yearly reproductive cycles may be performed (Caputo et al., 2011 b). Archaeolacerta bedriagae (Camerano, 1885) is a lizard (Lacertidae) restricted in its distribution to eastern Sardinia and Corsica and considered as "Near Threatened", the extension of crystalline rocky outcrop to which its populations are linked, being strategic for its survival; shelters at risk are satellite islands or small inland areas. Daily activity has been studied in the populations of Corsica between 1750 and $1800 \mathrm{~m}$ a.s.l. (however A. bedriagae is not exclusively a mountain species as regarded till up to thirty years ago). Activity is marked especially during spring time, being constant between 7:00 and 16:00-16:30 hours at sunset. Males explain a bimodal pattern of activity with the exception for the central hours of the day contrary to adult females which are active in the central hours of the day and at afternoon. The species has been observed on the sunny surface of the rocks; thermoregulation occurs in the hottest hours of the day too, lizards get out at their shelters with clouding over within an hour from passing sun. Average activity temperature is higher in A. bedriagae contrary to Podarcis tiliguerta (Gmelin, 1789) - the commonest and relatively ubiquitous lizard of the sardo-corso district - living sintopically in the same sites (Sindaco et al., 2011). Coronella girondica (Daudin, 1803) is a fine, small, thermo-xerophilous and oviparous snake of the family Colubridae with a Western-Mediterranean distributional range. In Italy, it is a rare species with the exception of few and relatively large areas such as Piedmont, Liguria and Tuscany; besides, many isolated European populations are at higher risk of extinction within few years. This species shows a remarkable ability pattern of adaptation in mediterranean / oceanic bioclimatic regions where it lives on stone areas of rocky slopes. Activity period begin at mid March or at the beginning of April lasting up to September in Central Italy. Males latency period is two weeks earlier than females, on the contrary hibernation is practically simultaneous. C. girondica shows an unimodal yearly cycle of activity contrary to many other species which live under Mediterranean bioclimatic conditions. This unusual phenological pattern may be related with the peculiar twilight and nocturnal daily activity of the species (Razzetti \& Bernini, 2011). Zamenis situla (Linnaeus, 1758), is a mid sized snake $(60-100 \mathrm{~cm})$ with a distributional Italian area confined to the south east of Apulia, Eastern Sicily and the Maltese Islands, few sites in Basilicata near the Apulia border are also known. Open areas with scrub vegetation and sparse rock surface are elective biotopes, the conservation and proper management of these ecosystems being strategical for the survival of Z. situla, considered as LC species according to IUCN categories. As a rule, the activity period extends from March to November; occasionally, individuals have been observed outside their shelters in wintertime during sunny and hot days - winter latency generally lasts from December to February. Activity pattern of this strictly daytime snakes - however some Authors suggest a nocturnal activity during hottest months too - is explained by two peaks, during February - March and during June, linked to breeding behaviour, which lasts up to May, and intense foraging behaviour, respectively. Newborns emerge between the end of August and September. A marked circadian activity rhythm may be observed between 7 to 10 hours during May and September and between 6 to 11 hours during June (Scillitani \& Turrisi, 2011). Vipera ursinii (Bonaparte, 1835) sensu lato 
has a wide geographic distribution that extends from Southern France to Eastern Asia, being part of a complex of several species or semi species whose origin goes back to the Pliocene (Cheylan et al., 2011). A recent revision changes substantially the validity of many taxa of this polytypic group. Particularly, among the five subspecies up to now considered valid, the nominal one, $V . u$. ursinii, is exclusive of some areas of the Central Apennines and some mountainous areas of south-eastern France (Nilson \& Andrén, 2001; Filippi et al., 2011). Orsini's viper is the smallest viper in Europe and the smallest snakes of Italy and France, adults are $40-45 \mathrm{~cm}$ long, a very large adult female may reach $50 \mathrm{~cm}$. This snake is associated with open areas such as grasslands and steppes. In the Central Apennines it is almost exclusively linked to mountain areas characterized by the outcrop of fissured limestone on which extensive formations of Juniperus nana and Pinus mugo - a bearing prostrate shrub groves. The influence of seasonal conditions of the habitat in which its populations evolve is marked. Phenological pattern are correlated with the existence of two distinct activity phases, a long latency period in autumn-winter and an activity period between late spring and the end of summer. The species shows the shortest cycle of activity among Italian snakes. Males first are vagrant not before the end of April, followed by females two or three weeks after and adults came back inside their winter shelters between mid September - mid October. Winter spermatogenesis is typical of males. Foraging activity falls between June and September, mating activity during the second half of May; ovulation falls at the end of June, birth during late summer. Being ovoviviparous, $V$. ursinii give birth perfectly developed and self-sufficient newborns, $15 \mathrm{~cm}$ long. Unfortunately, this small, attractive, viper is a priority for biodiversity conservation in Italy and the whole Europe. Many Apennine populations are more or less critically endangered owing to the following risk factors; 1- mountain overgrazing of domestic and semi domestic cattle; 2- high population density of some ungulate, particularly the wild boar Sus scrofa Linnaeus, 1758; 3- intentional killing by man or provoked by car traffic at highest altitude; 4- modification and / or destruction of natural habitats (Cheylan et al., 2011; Filippi et al., 2011).

\section{Conclusion}

To sum up, it is hardly feasible to overestimate the influence of temperature on reproductive cycle and migration of Italian (and European) amphibians, especially newts, and reptiles. Global Climatic Changes - including high levels of incident solar radiation- in unison with habitat alterations are responsible for the biodiversity crisis of Italian (and European) populations of Amphibia. The following steps attract reader's attention on the landmarks up to now focalized. Ecological modelling approaches to the change of habitat suitability is a powerful tool in the study of short and long-term conservation of endangered species. An up-to-date knowledge of the present distribution of a given species in a certain territory and climatic scenario is required. Such examples are numerous in the various countries; for instance, in Italy, the databank is linked to the so-called CKmap' initiative which is supported financially by the Italian Ministry for the Environment, Land and Sea Protection (Blasi et al., 2007). Environmental factors related to species occurrence and present suitable areas, clearly represent the rudiments of this approach. Further on, both land cover and morphology together with human impact layers are considered as covariates to climatic predictors. Different methods for modelling habitat suitability and binary predictions (presence / absence of the species) are performed. Models may be applied for some time 
slices, present and future - at selected intervals, e.g. 2030, 2050, 2070. Results indicate which squares of the CKmap loose completely their suitability within a certain period. Present conditions with currently known distribution and different (hypothetical) climatic scenarios and environmental changes may be compared. Existing controversies in the field of climatic (and related) phenomena are pointed out. The efficiency of predictions is influenced by many factors; the simplistic assumption that some factors remain unchanged drives to under / over estimation of the persistence probability of the species under the spotlight. A dramatic perspective is the complete extinction from the Central Mediterranean Ecoregion of $H$. hippocrepis during the next decades; immediate actions for habitat conservation should be organized by the pertinent authorities (Corti et al., 2000). However, the near future will reserve to mankind enormous challenges in the light of supporting and preserving both geodiversity and biodiversity of the Mediterranean Ecoregion.

\section{Acknowledgments}

The Author is indebted to all those provide useful suggestions, first with Luca Luiselli for the critical review of the manuscript and Giovanni Amori which provides bibliographical sources. Francesca Santamaria improves the English style. Peoples of the Società Romana di Scienze Naturali provide helpful assistance, particularly Chiara Bufalieri and Federica Emiliani. Finally, the Author is really thankful to anonymous reviewers for their extremely careful comments.

\section{References}

Accordi, F., Massarek, A. \& Nobili, G. (1990). Ecological responses in a population of smooth newts (Triturus vulgaris meridionalis) in an unpredictable environment. Herpetological Journal, Vol. 1, pp. 509-513.

Alford, R. A. \& Richards, S. J. (1999). Global amphibian declines: a problem in applied ecology. Annual Review of Ecology and Systematic, Vol. 30, pp. 133 - 165.

Andreone, F. \& Luiselli, L. (2000). The Italian batrachofauna and its conservation status: a statistical assessment. Biological Conservation, Vol. 96, pp. 197-208.

Angelini, C., Antonelli, D. \& Utzeri, C. (2001). Aspetti della fenologia riproduttiva di Salamandrina terdigitata (Lacépède, 1788). Pianura, Vol. 13, pp. 105-108.

Angelini, C., Vanni, S. \& Vignoli L. (2007). Salamandrina terdigitata (Bonnaterre, 1789) Salamandrina perspicillata (Savi, 1821), pp. 228-237. In: Lanza, B., Andreone, F., Bologna, M. A., Corti, C. \& Razzetti, E. (eds.) (2007). Fauna d'Italia. XLII. Amphibia., "Calderini - Edizioni Calderini de Il Sole 24 ORE Editoria Specializzata S. r. 1." Bologna, ISBN -978-88-506-5256-3.

Angelini, C., Antonelli, D. \& Utzeri, C. (2010 a ). Capture-mark-recapture analysis reveal survival correlates in Salamandrina perspicillata, Amphibia-Reptilia, Vol. 31, pp. 21-26.

Angelini, C., Cari, B. \& Utzeri, C. (2010 b). Studio della dinamica di una popolazione di Lissotriton italicus dei Monti Ausoni (Lazio), pp. 195-198. In: Di Tizio, L., Di Cerbo, A. R., Di Francesco, N. \& Cameli, A. (eds.) (2010). Atti VIII Congresso Nazionale Societas Herpetologica Italica, Chieti 22-26 settembre 2010, Ianieri Edizioni, Pescara. 
Aprea, G., Lo Cascio, P., Corti, C. \& Zuffi, M.A.L. (2011). Tarentola mauritanica (Linnaeus, 1758), pp. 277-285. In: Corti, C.; Capula, M. Luiselli, L. Razzetti, E. \& Sindaco, R. (2011). Fauna d'Italia. XLV. Reptilia, "Calderini - Edizioni Calderini de Il Sole 24 ORE S.p.A." Milano, ISBN -978-88-506-5390-4.

Araújo, M.B., Thuiller, W. \& Pearson, R.G. (2006). Climate warming and the decline of amphibians and reptiles in Europe. Journal of Biogeography, Vol. 33, pp. 1712-1728.

Bassu, L., Nulchis, V., Satta, M. G., Fresi, C. \& Corti, C. (2008). Atlas of amphibians and reptiles of Sardinia - state of the art and general considerations, pp. 52-58. In: Corti C. (ed.) (2008). Herpetologia Sardiniae. Societas Herpetologica Italica / Edizioni Belvedere, Latina "le scienze" (8).

Bassu, L., Nulchis, V., Satta, M. G., Fresi, C. \& Corti, C. (2010), Anfibi e Rettili di Sardegna II, brevi considerazioni sulla loro distribuzione, pp. 19-26. In: Di Tizio, L., Di Cerbo, A. R., Di Francesco, N. \& Cameli, A. (eds.) (2010). Atti VIII Congresso Nazionale Societas Herpetologica Italica, Chieti 22-26 settembre 2010, Ianieri Edizioni, Pescara.

Bianchi, C. N., Boero, F., Fraschetti, S. \& Morri, C. (2002). La fauna del Mediterraneo, pp. 248-335. In: Minelli, A., Chemini, C., Argano, R. \& Ruffo, S. (eds.) (2002). La fauna in Italia. Touring Editore, Milano e Ministero dell'Ambiente e della Tutela del Territorio, Roma.

Blasi, C. (1994). Fitoclimatologia del Lazio. Università "La Sapienza" e Regione Lazio, Assessorato Agricoltura-Foreste Caccia e Pesca, Usi Civici.

Blasi, C. \& Michetti, L. (2007). Biodiversity and Climate, pp. 57-66. In: Blasi, C. (ed. in chief), Boitani, L., La Posta, S., Manes, F. \& Marchetti, M. (2007). Biodiversity in Italy. Contribution to the National Biodiversity Strategy. Palombi \& Partner s. r. 1. , Roma, ISBN 978-88- 6060-041-7.

Blasi, C. (ed. in chief), Boitani, L., La Posta, S., Manes, F. \& Marchetti, M. (2007). Biodiversity in Italy. Contribution to the National Biodiversity Strategy. Palombi \& Partner s. r. 1. , Roma, ISBN 978-88- 6060-041-7.

Bologna, M. A., Capula, M. \& Carpaneto, G. M. (eds.) (2000). Anfibi e Rettili del Lazio. Fratelli Palombi Editori, Roma.

Bombi, P., Capula, M., D'Amen, M. \& Luiselli, L. (2011). Climate change threatens the survival of highly endangered Sardinian populations of the snake Hemorrhois hippocrepis. Animal Biology, Vol. 61, pp. 239-248.

Brandmayr, P. \& Ghirardelli, E. (1995). Gli animali e l'ambiente: ecologia, pp. 469 - 603. In: Baccetti, B., Baldaccini, N. E., Bedini, C., Brandmayr, P., Capanna, E., Chieffi, G., Cobolli, M., Ferraguti, M., Ghirardelli, E., Ghiretti, F., Giusti, F., Grigolo, A., Mainardi, D., Minelli, A., Papi, F., Parrinello, N., Ricci, N., Ruffo, S., Sarà, M., Scali, V. \& Zullini, A. (1985). Zoologia. Trattato Italiano. Zanichelli Editore S.p.A., Bologna.

Caldonazzi, M., Nistri, A. \& Tripepi, S. (2007). Salamandra salamandra (Linnaeus, 1758), pp. 221-227. In: Lanza, B., Andreone, F., Bologna, M. A., Corti, C. \& Razzetti, E. (eds.) (2007). Fauna d'Italia. XLII. Amphibia., "Calderini - Edizioni Calderini de Il Sole 24 ORE Editoria Specializzata S. r. 1.." Bologna, ISBN -978-88-506-5256-3.

Caputo, V., Guarino, F.M. \& Giovannotti, M. (2011 a). Chalcides chalcides (Linnaeus, 1758), pp. 298-310. In: Corti, C.; Capula, M. Luiselli, L. Razzetti, E. \& Sindaco, R. (2011). Fauna d'Italia. XLV. Reptilia, "Calderini - Edizioni Calderini de Il Sole 24 ORE S.p.A." Milano, ISBN -978-88-506-5390-4. 
Caputo, V., Lo Cascio, P. Turrisi, G.F. \& Vaccaro, A. (2011 b). Chalcides ocellatus (Forskål, 1775), pp. 310-322. Corti, C.; Capula, M. Luiselli, L. Razzetti, E. \& Sindaco, R. (2011). Fauna d'Italia. XLV. Reptilia, "Calderini - Edizioni Calderini de Il Sole 24 ORE S.p.A." Milano, ISBN -978-88-506-5390-4.

Cattaneo, A. (1985). Il colubro ferro di cavallo dell'isola di Pantelleria: Coluber hippocrepis nigrescens subsp. nova (Reptilia Squamata Colubridae). Atti della Società italiana di Scienze naturali e del Museo civico di Storia naturale di Milano, Vol. 126: 165-184.

Cheylan, M., Corti, C., Carpaneto, G.M., Mazzotti, S. \& Zuffi, M.A.L. (2011). Testudo hermanni Gmelin, 1789, pp. 188-199. In: Corti, C.; Capula, M. Luiselli, L. Razzetti, E. \& Sindaco, R. (2011). Fauna d'Italia. XLV. Reptilia, "Calderini - Edizioni Calderini de Il Sole 24 ORE S.p.A." Milano, ISBN -978-88-506-5390-4.

Cheylan, M., Croquet, V., Dragone, C., Ferchaud, A-L. Garcia, A., Lisse, H., Lyet, A., Reboul, D. \& Reyna K. (2011). Technical guide to manage and monitor populations of Orsini's viper. ARPE-Corinne Dragone; CEEP-Hèlène Lisse.

Collins, J. P. \& Storfer, A. (2003). Global amphibian declines: sorting the hypotheses. Diversity and Distributions, Vol. 9, pp. 89 -98.

Corsetti, L. \& Romano, A. (2008). On the occurrence of the Italian Aesculapian snake, Zamenis lineatus (Camerano, 1891), in Latium (Central Italy). Acta Herpetologica, Vol. 3, pp. 179-183.

Corti, C., Luiselli, L., Filippi, E. \& Capula, M. (2000). Distribution, natural history and morphometrics of the critically endangered Coluber hippocrepis populations of Sardinia: a review, with additional data and conservation implications. AmphibiaReptilia, Vol. 21, pp. 279-287.

Corti, C., Capula, M. Luiselli, L. Razzetti, E. \& Sindaco, R. (2011). Fauna d'Italia. XLV. Reptilia, "Calderini - Edizioni Calderini de Il Sole 24 ORE S.p.A." Milano, ISBN -978-88-5065390-4.

Crucitti, P. (2011). Bats of Latium: A review of past and recent studies and the contribution of B. Lanza. Hystrix It. J. Mamm. (n. s.), Vol. 22, pp. 15-22.

Crucitti, P, Brocchieri, D, Emiliani, F., Malori, M., Pernice, S., Tringali, L. \& Welby, C. (2010). Amphibians of the Simbruini Mountains (Latium, Central Italy). Acta Herpetologica, Vol. 5, pp. 91-101.

D'Amen, M. \& Bombi, P. (2009). Global warming and biodiversity: Evidence of climatelinked amphibian declines in Italy. Biological Conservation, Vol. 142, pp. 3060-3067.

Del Vecchio, S., Burke, R.L., Rugiero, L., Capula, M. \& Luiselli, L. (2011). Seasonal changes in the diet of Testudo hermanni hermanni in Central Italy. Herpetologica, Vol. 67, pp. 236249.

Di Rosa, I., Simoncelli, F., Fagotti, A. \& Pascolini, R. (2007). The proximate cause of frog decline ?. Nature, Vol. 447, E4-E5.

Filippi, E. \& Luiselli, L. (2000). Status of the Italian snake-fauna and assessment for conservation threats. Biological Conservation, Vol. 93, pp. 219-225.

Filippi, E., Capula, M., Luiselli, L. \& Rugiero, L. (2011). Vipera ursinii (Bonaparte, 1835), pp. 623-627. In: Corti, C., Capula, M. Luiselli, L. Razzetti, E. \& Sindaco, R. (2011). Fauna d'Italia. XLV. Reptilia, "Calderini - Edizioni Calderini de Il Sole 24 ORE S.p.A." Milano, ISBN -978-88-506-5390-4. 
Gatto, M., Zingone, A., Fiorese, G. \& De Leo G. A. (2009). La biodiversità nell'era dei cambiamenti climatici: un'eredità da salvaguardare, pp. 295 - 335, In: Castellari, S. \& Artale, V. (Ed.) (2009). I cambiamenti climatici in Italia: evidenze, vulnerabilità $e$ impatti. Bononia University Press, Bologna. ISBN: 978-88-7395-484-2.

Giacoma, C. (1988). The ecology and distribution of newts in Italy. Ann. Ist. Mus. Zool., Univ. Napoli, Vol. 26, pp. 49-84.

Grill, A., Casula, P., Lecis, R. \& Menken, S. (2007). Endemism in Sardinia, pp. 273-296. In: Weiss, S. \& Ferrand, N. (eds.) (2007). Phylogeography of southern refugia. Springer, Dordrecht.

Lanza, B.; Azzaroli, M. L., Borri, M., Poggesi M. \& Vanni, S. (1982). Dizionario del Regno Animale. Arnoldo Mondadori Editore S.p.A., Milano.

Lanza, B.; Andreone, F., Bologna, M. A., Corti, C. \& Razzetti, E. (eds.) (2007). Fauna d'Italia. XLII. Amphibia., "Calderini - Edizioni Calderini de Il Sole 24 ORE Editoria Specializzata S. r. 1.." Bologna, ISBN -978-88-506-5256-3.

Lanza, B.; Nistri, A. \& Vanni, S. (2009). Anfibi d'Italia. Quaderni di Conservazione della Natura; numero 29. Ministero dell'Ambiente e della Tutela del Territorio e del Mare, I.S.P.R.A., Grandi \& Grandi Editori.

Lecis, R. (2004). The endemic Sardinian newt Euproctus platicephalus: local threats and population decline. Italian Journal of Zoology, suppl. Vol. 2, pp. 195-198.

Lecis, R. (2007). Euproctus platicephalus (Gravenhorst, 1829), pp. 192-197. In: Lanza, B., Andreone, F., Bologna, M. A., Corti, C. \& Razzetti, E. (eds.) (2007). Fauna d'Italia. XLII. Amphibia., "Calderini - Edizioni Calderini de Il Sole 24 ORE Editoria Specializzata S. r. 1.." Bologna, ISBN -978-88-506-5256-3.

Lionello, P., Baldi, M., Brunetti, M., Cacciamani, C., Maugeri, M., Nanni, T., Pavan, V. \& Tomozeiu R. (2009). Eventi climatici estremi: tendenze attuali e clima futuro sull'Italia, pp. 81-106. In: Castellari S. \& Artale, V. (Ed.) (2009). I cambiamenti climatici in Italia: evidenze, vulnerabilità e impatti. Bononia University Press, Bologna. ISBN: 978-88-7395-484-2.

Luiselli, L. (2006 a). Resource partitioning in the communities of terrestrial turtles: A review of the evidences. Revue d' Ecologie (Terre et Vie), Vol. 61, pp. 353-365.

Luiselli, L. (2006 b). Food niche overlap between sympatric potential competitors increases with habitat alteration at different trophic levels in rain-forest reptiles (omnivorous turtles and carnivorous vipers). Journal of Tropical Ecology, Cambridge, Vol. 22, pp. 695-704.

Luiselli, L., Corti, C., Salvi, D. \& Capula, M. Hemorrhois hippocrepis (Linnaeus, 1758), pp. 500506. In: Corti, C., Capula, M. Luiselli, L. Razzetti, E. \& Sindaco, R. (2011). Fauna d'Italia. XLV. Reptilia, "Calderini - Edizioni Calderini de Il Sole 24 ORE S.p.A." Milano, ISBN -978-88-506-5390-4.

Minelli, A., Chemini, C., Argano, R. \& Ruffo, S. (eds.) (2002). La fauna in Italia. Touring Editore, Milano e Ministero dell' Ambiente e della Tutela del Territorio, Roma.

Nanni, T., Maugeri, M. \& Brunetti, M. (2009). La variabilità e le tendenze del clima in Italia nel corso degli ultimi due secoli, pp. 11-45. In: Castellari S. \& Artale, V. (Ed.) (2009). I cambiamenti climatici in Italia: evidenze, vulnerabilità e impatti. Bononia University Press, Bologna. ISBN: 978-88-7395-484-2. 
Nilson, G. \& Andrén, C. (2001). The meadow and steppe vipers of Europe and Asia - the Vipera (Acridophaga) ursinii complex. Acta Zoologica Academiae Scientiarum Hungaricae, Vol. 47, pp. 87-267.

Pizzuti Piccoli, A. (2006/07). Fenologia riproduttiva del tritone punteggiato Lissotriton vulgaris meridionalis (Boulenger, 1882), (Amphibia, Urodela) nel Bosco di Palo (Roma). Ann. Mus. civ. St. nat. Ferrara, Vol. 9/10, pp. 99-110.

Razzetti, E. \& Bernini, F. (2011). Coronella girondica (Daudin, 1803), pp. 481-487. In: Corti, C.; Capula, M. Luiselli, L. Razzetti, E. \& Sindaco, R. (2011). Fauna d'Italia. XLV. Reptilia, "Calderini - Edizioni Calderini de Il Sole 24 ORE S.p.A." Milano, ISBN -978-88-5065390-4.

Ruffo, S. \& Stoch, F. (eds.) (2005). Checklist e distribuzione della fauna italiana . Memorie del Museo Civico di Storia Naturale di Verona, Verona.

Sacchi, R. \& Delaugerre, M. (2011). Hemidactylus turcicus (Linnaeus, 1758), pp. 271-276. In: Corti, C.; Capula, M. Luiselli, L. Razzetti, E. \& Sindaco, R. (2011). Fauna d'Italia. XLV. Reptilia, "Calderini - Edizioni Calderini de Il Sole 24 ORE S.p.A." Milano, ISBN -978-88-506-5390-4.

Salvidio, S., Lanza, B. \& Delaugerre, M. (2011). Euleptes europaea (Gené, 1839), pp. 258-270. In: Corti, C., Capula, M. Luiselli, L. Razzetti, E. \& Sindaco, R. (2011). Fauna d'Italia. XLV. Reptilia, "Calderini - Edizioni Calderini de Il Sole 24 ORE S.p.A." Milano, ISBN -978-88-506-5390-4.

Scillitani, G. \& Tripepi, S. (2007). Lissotriton italicus (Peracca, 1898), pp. 239-246. In: Lanza, B., Andreone, F., Bologna, M. A., Corti, C. \& Razzetti, E. (eds.) (2007). Fauna d'Italia. XLII. Amphibia., "Calderini - Edizioni Calderini de Il Sole 24 ORE Editoria Specializzata S. r. 1.." Bologna, ISBN -978-88-506-5256-3.

Scillitani, G. \& Turrisi, G. F. (2011). Zamenis situla (Linnaeus, 1758), pp. 591-599. In: Corti, C.; Capula, M. Luiselli, L. Razzetti, E. \& Sindaco, R. (2011). Fauna d'Italia. XLV. Reptilia, "Calderini - Edizioni Calderini de Il Sole 24 ORE S.p.A." Milano, ISBN -978-88-5065390-4.

Sciortino, M., Luise, A. \& Genesio, L. (2009). La desertificazione e il degrado del territorio, pp. 160-174. In: Castellari S. \& Artale, V. (Ed.) (2009). I cambiamenti climatici in Italia: evidenze, vulnerabilità e impatti. Bononia University Press, Bologna. ISBN: 978-887395-484-2.

Simoncelli, F., Fagotti, A., Dall'Olio, R., Vagnetti, D., Pascolini, R. \& Di Rosa, I. (2005). Evidence of Batrachochytrium dendrobatidis infection in Water frogs of Rana esculenta complex in Central Italy. Ecohealth, Vol. 2, pp. 307-312.

Sindaco, R.; Doria, G., Razzetti, E. \& Bernini, F. (eds.).(2006). Atlante degli Anfibi e dei Rettili d'Italia. Atlas of Italian Amphibians and Reptiles. Edizioni Polistampa, Firenze, ISBN 88-8304-941-1.

Sindaco, R., Bombi, P., Salvi, D. \& Corti, C. (2011). Archaeolacerta bedriagae (Camerano, 1885), pp. 341-348. In: Corti, C.; Capula, M. Luiselli, L. Razzetti, E. \& Sindaco, R. (2011). Fauna d'Italia. XLV. Reptilia, "Calderini - Edizioni Calderini de Il Sole 24 ORE S.p.A." Milano, ISBN -978-88-506-5390-4.

Speight, M.R., Hunter, M.D. \& Watt, A.D. 2008. Ecology of Insects. Concepts and Application, Wiley-Blackwell, Oxford, UK, ISBN 978-1-4051-3114-8. 
Stoch, F. (2000-2005). CKmap 5.3.8. Ministero dell'Ambiente e della Tutela del Territorio, Dir. Prot. Nat.

http://www.minambiente.it/index.php?id_sezione=1930 (downloaded on January 2008).

Stuart, S.N., Chanson, J.S., Cox, N.A., Young, B.E., Rodrigues, A.S.L., Fischman, D.L. \& Waller, R.W. (2004). Status and trends of amphibian declines and extinctions worldwide. Science, Vol. 306, pp. 1783 - 1786.

Tedaldi, G. (2001). La salamandra pezzata nell'Appennino tosco-romagnolo e in alcune zone limitrofe dell'Emilia, della Toscana e delle Marche: stato attuale delle conoscenze e problemi di conservazione, pp. 129-132. In: Barbieri, F., Bernini, F. \& Fasola, M. (eds.) (2001). Atti $3^{\circ}$ Congresso Nazionale Societas Herpetologica Italica, Pavia (2000). Pianura, Cremona.

Thomas, C.D., Cameron, A., Green, R.E., Bakkenes, M., Beaumont, L.J., Collingham, Y.C., Erasmus, B.F. N., de Siqueira, M.F., Grainger, A., Hannah, L., Huges, L., Huntley, B., van Jaarsveld, A.S. Midgley, G.F., Miles, L., Ortega-Huerta, M.A., Peterson, A.T., Phillips, O.L. \& Williams, S.E. (2004). Extinction risk from climate change. Nature, Vol. 427, pp. 145-148.

Veith, M., Mucedda, M., Kiefer, A. \& Pidinchedda, E. (2011). On the presence of pipistrelle bats (Pipistrellus and Hypsugo; Chiroptera Vespertilionidae) in Sardinia. Acta Chiropterologica, Vol. 13, pp. 89-99. 


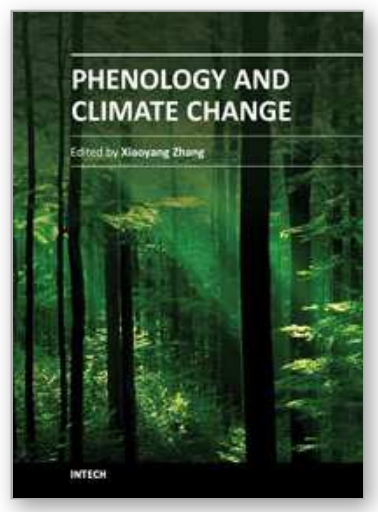

\author{
Phenology and Climate Change \\ Edited by Dr. Xiaoyang Zhang
}

ISBN 978-953-51-0336-3

Hard cover, 320 pages

Publisher InTech

Published online 21, March, 2012

Published in print edition March, 2012

Phenology, a study of animal and plant life cycle, is one of the most obvious and direct phenomena on our planet. The timing of phenological events provides vital information for climate change investigation, natural resource management, carbon sequence analysis, and crop and forest growth monitoring. This book summarizes recent progresses in the understanding of seasonal variation in animals and plants and its correlations to climate variables. With the contributions of phenological scientists worldwide, this book is subdivided into sixteen chapters and sorted in four parts: animal life cycle, plant seasonality, phenology in fruit plants, and remote sensing phenology. The chapters of this book offer a broad overview of phenology observations and climate impacts. Hopefully this book will stimulate further developments in relation to phenology monitoring, modeling and predicting.

\title{
How to reference
}

In order to correctly reference this scholarly work, feel free to copy and paste the following:

Pierangelo Crucitti (2012). A Review of Phenological Patterns of Amphibians and Reptiles in Central Mediterranean Ecoregion, Phenology and Climate Change, Dr. Xiaoyang Zhang (Ed.), ISBN: 978-953-510336-3, InTech, Available from: http://www.intechopen.com/books/phenology-and-climate-change/a-review-ofphenological-patterns-of-amphibians-and-reptiles-in-central-mediterranean-ecoregion

\section{INTECH}

open science | open minds

\author{
InTech Europe \\ University Campus STeP Ri \\ Slavka Krautzeka 83/A \\ 51000 Rijeka, Croatia \\ Phone: +385 (51) 770447 \\ Fax: +385 (51) 686166 \\ www.intechopen.com
}

\author{
InTech China \\ Unit 405, Office Block, Hotel Equatorial Shanghai \\ No.65, Yan An Road (West), Shanghai, 200040, China \\ 中国上海市延安西路65号上海国际贵都大饭店办公楼 405 单元 \\ Phone: +86-21-62489820 \\ Fax: +86-21-62489821
}


(C) 2012 The Author(s). Licensee IntechOpen. This is an open access article distributed under the terms of the Creative Commons Attribution 3.0 License, which permits unrestricted use, distribution, and reproduction in any medium, provided the original work is properly cited. 